\title{
TIMSS 2015 Matematik Başarısını Etkileyen Değişkenlerin Yapısal Eşitlik
} Modeli ile İncelenmesi*

\section{The Investigation of the Variables Effecting TIMSS 2015 Mathematics Achievement with SEM}

\author{
Zafer Ertürk \\ Gazi Üniversitesi \\ zerturk35@gmail.com \\ Oya Erdinç Akan \\ Gazi Üniversitesi \\ oyaerdincakan@gmail.com
} Alıntılama: Ertürk, Z. \& Erdinç Akan, O. (2018). TIMSS 2015 Matematik başarısını etkileyen değişkenlerin
yapısal eşitlik modeli ile incelenmesi. Ulusal Eğitim Akademisi Dergisi (UEAD), 2(2), 14-34.

Geliş tarihi:

16 Mart 2018

Kabul tarihi:

12 Eylül 2018

Sorumlu yazar:

Zafer Ertürk

zerturk35@gmail.com

(C) 2018 UEAD.

Bütün hakları saklıdır.
Ozet: Bu çalışmada, TIMSS 2015 matematik başarı testini alan dördüncü ve sekizinci sınıf öğrencilerinin matematik başarısını etkileyen değişkenler incelenmiştir. Bu amaç doğrultusunda matematiği sevme, matematiğe olan ilgi, matematiğe ilişkin özgüven, ev ortamı ve okul ortamı değişkenlerini kullanarak, öğrencilerin matematik başarısının bağımlı değişken olduğu yapısal bir model kurulmuştur. Matematik başarısı ile ilgili değişkenlerin incelendiği bu araştırmanın türü, ilişkisel tarama modelidir. Araştırmanın çalışma grubunu TIMSS 2015 çalışmasına Türkiye'den katılan dördüncü sınıf düzeyinde 6456 öğrenci, sekizinci sınıf düzeyinde ise 6079 öğrenci oluşturmaktadır. Araştırmada öğrencilerin matematik başarıları ile ilgili değişkenler öğrenci anketlerinden elde edilmiştir.Verinin analizi için ilk olarak her bir değişkenin belirlenmesinde açımlayıcı faktör analizi kullanılmıştır. Daha sonra, yapısal eşitlik modellemesi kullanılarak her bir sınıf düzeyinde matematik başarısı ile ilişkili değişkenlerin etkisi incelenmiştir. Araştırma bulgularına göre, bağımsız değişkenler dördüncü sınıf düzeyinde matematik başarısındaki değişkenliğin \%47'sini açıklarken, sekizinci sınıf düzeyinde \%49'unu açıklamaktadır. Matematiğe ilişkin özgüven değişkeni her iki sınıf seviyesinde de matematik başarısı ile ilişkili en önemli değişkendir. Dördüncü sınıf seviyesinde matematiğe olan ilgi, öğrencilerin matematik başarıları ile pozitif bir ilişki gösterirken, sekizinci sınıflarda negative bir ilişki sergilemektedirler. Okul ortamı değişkeni ise her iki sınıf seviyesinde negatif ve küçük etkiye sahiptir.

Anahtar kelimeler: TIMSS, yapısal eşitlik modeli, matematik başarısı

Received:

16 March 2018

Accepted:

12 September 2018

Abstract: In this study, variables affecting the mathematics achievement of fourth and eighth grade students taking the TIMSS 2015 mathematics achievement test were examined. In line with this purpose, a structural model in which students' mathematics achievement is the dependent variable has been established with liking mathematics, interest in mathematics, mathematics self-confidence, home environment and school environment independent variables. The type of this research that examines the

Corresponding author:

Zafer Ertürk

zerturk35@gmail.com variables related to mathematics success is the relational screening model. The study group of the research consists of 6456 fourth grade and 6079 eight grade students

* Bu çalışmanın bir kısmı Uluslararası Bilim ve Eğitim Kongresi’nde (23- 25 Mart 2018, Afyon Kocatepe Üniversitesi, Afyon) sözlü bildiri olarak sunulmuştur. 
(C) 2018 UEAD.

All rights reserved. participated in TIMSS 2015 study from Turkey. The variables related to students' mathematics achievement were obtained from student questionnaries. Firstly, EFA was used in specification of each variable in the analysis of the data. Then, the effect of the variables related to mathematics achievement in each grade was investigated using Structural Equation Modeling. According to the findings, while the independent variables explain $47 \%$ of the variety in mathematics achievement of fourth grade students, they explain $49 \%$ of it in eight grade. Mathematics self-confidence is the most important variable related to maths achievement in both grades. Interest in mathematics is related to students' maths achievement positively whereas it has a negative relation in eight grade. School environment has a negative relation and small effect.

Keywords: TIMSS, structural equation model, mathematics achievement

\section{Giriş}

TIMSS Uluslararası Matematik ve Fen Eğilimleri Araştırması (TIMSS-Trends in International Mathematics and Science Study), Uluslararası Eğitim Başarılarını Değerlendirme Kuruluşu (IEA- International Association for the Evaluation of Educational Assessment) tarafindan yürütülen katılımcı ülkelerin eğitim düzeylerini uluslarası alanda karşılaştırma imkanı tanıyan bir değerlendirme platformudur. TIMSS' in genel amacı, çalışmaya katılan ülkelerin matematik ve fen öğrenimini ve öğretimini geliştirmek için ülkelerin uyguladıkları programların, öğretim yöntemlerinin ve bunların öğrencilerin başarıları ile ilişkilerini belirlemeye çalışmaktır (Robitaille ve Robeck, 1996). TIMSS, çalışmaya katılan ülkelerin iki ayrı eğitim seviyesindeki (4. ve 8. sınıf) öğrencilerin matematik ve fen alanlarındaki başarılarını değerlendirmektedir. Öğrenmede sadece bilişsel faktörlerin ve süreçlerin değil, aynı zamanda çevresel faktörlerin (Bandura, 1986; Wood ve Bandura, 1989) ve duyuşsal faktörlerinde rol oynadığı (Bloom, 2012), göz önüne alınarak TIMSS uygulamalarında başarı testlarının yanında öğrencilerin duyuşsal özellikleri, okul ortamı ve ev ortamı özelliklerinide ölçen anketler kullanılmaktadır. Öğrencilerin cinsiyet, yaş, aile yapısı, yaşadığı çevre, okula ilişkin özelliklerin belirlemesinde öğrencilere, ailelere ve okul yöneticilerine bu anketler uygulanmaktadır. Böylece öğrencilerin matematik ve fen başarı seviyeleri ölçülürken başarı ile ilgili olduğu düşünülen değişkenlere ilişkin bilgilerde elde edilebilmektedir. Öğrenci anketleri ile öğrencilerin fen ve matematik başarılarına etki eden özellikler ortaya çıkarılabilmektedir. (Bos ve Kuiper, 1999; House, 2006; Koballa ve Glynn, 2004; Leung, 2002; Shen, 1999).

TIMSS verisinin öğrenciler hakkında geniş bilgiler vermesi nedeni ile birçok araştırmacı tarafindan bu veri seti kullanılarak, öğrencilerin başarılarında etkili olan birçok değişken incelenmektedir. Berberoğlu, Çelebi, Özdemir, Uysal ve Yayan (2003)'ın TIMSS 1999 verilerini kullanılarak yaptıkları çalışmada, öğrencilerin fen ve matematik başarılarını etkileyen faktörleri belirlemek için öğretim etkinlikleri, sosyo-ekonomik düzey, öğrencilerin başarı-başarısızlık algısı gibi boyutların yer aldığı bir model kurulmuştur. Çalışmanın sonuçlarına göre, matematik ve fen başarılarını etkileyen en önemli faktörlerin, öğrencilerin başarı-başarısızlık algıs1 ve sosyoekonomik düzeyi olduğu bulunmuştur. Benzer şekilde Yayan (2003) tarafindan yapılan çalışmada ise okul dışı aktiviteler, matematiğe verilen önem, matematik dersi için sınıf iklimi algısı, başarısızlık algısı, öğretmen merkezli ve öğrenci merkezli etkinlikler değişkenleri ile bir yapısal eşitlik modeli kurulmuştur. Kurulan model aracıllğıyla Türkiye, Hollanda ve İtalya örneklemleri üzerinde yukarıda belirtilen değişsenlerin matematik başarısı arasındaki ilişkiler incelenmiştir. Yapılan bu çalışmada da başarısızlık algısının, sosyo-ekonomik durumun ve öğrenci merkezli etkinliklerin her üç ülkede de sekizinci sınıf öğrencilerinin matematik başarılarını en iyi yordayan değişkenler olduğu görülmüştür. Akyüz (2014), TIMSS 2011 Türkiye, Singapur, 
Amerika Birleşik Devletleri ve Finlandiya verilerini kullanılarak öğrenci ve okul özelliklerinin matematik başarısına etkisini hiyerarşik modelleme tekniği ile incelemiştir. Çalışmada öğrenci anketinden elde edilen matematiği sevme, matematiğe ilişkin özgüven, matematik öğrenmeye karş1 ilgi, evdeki eğitsel kaynaklar, zorbalığa maruz kalma, ebeveyn eğitim düzeyi gibi değişkenlerinin kullanılmıştır. Öğrenci düzeyinde dört ülke içinde matematiğe ilişkin özgüvenin ve evde bulunan eğitsel kaynakların, okul düzeyinde ise okuldaki öğrencilerin sosyo-ekonomik durumlarının matematik başarısını en çok yordayan değişkenler olduğu sonucuna ulaşılmıştır.

Öğrencilerin matematik öğrenmelerinde çok önemli bir yer tutan duyşsal alan özellikleri, öğrencilerin başarılarını belirlemede kullanılan özelliklerin başında gelmektedir. Duyuşsal alan özellikleri öğrencilerin düşünme, harekete geçme gibi aktivetilerinde önemli görünmekte ve öğrencilerin başarılarındaki farklılıkların neredeyse dört birini oluşturmaktadır (Bloom, 2012). Duyuşsal özellikler içerisinde sorumluluk sahibi olma, işbirliği yapabilme, tutum, değer verme, sevme, özgüven, ilgi duyma vb. yer almaktadır (Mcmillian, 2015). Öğrenci başarılarında çok önemli bir yeri olmasına ragmen, eğitm sistemi içerisinde öğrencilerin duyuşsal özellikleri çok fazla dikkate alınmamakta, daha çok bilişsel özelliklerin geliştirilmesine yönelik çalışmalar yapılmaktadır. Oysaki literatür incelendiği zaman duyuşsal alan özelliklerinin öğrencilerin başarılarını açıklamada önemli bir değişken olduğu görülmektedir (Akyüz, 2014; Çavdar, 2015; Doğan ve Barış, 2010; Leder ve Forgasz, 2006; Yayan, 2003).

Duyuşsal alan özellikleri içinde matematik başarısını etkilyen önemli değişkenlerin başında özgüven gelmektedir. Özgüven, bireyin gerçekleştirmesi gereken performans ile kendi kapasitesini karşılaştırıp, duruma göre harekete geçmesi ve bireyin karşılaşmış olduğu güçlüklerde nasıl başarılı olabileceğine ilişkin kendisi hakkındaki inancıdır (Bayrakçı, 2007). Yapılan çalışmalarla başarı üzerinde sürekli etkisi incelenen çalışmalara göre öğrencilerin matematiğe ilişkin özgüvenleri arttıkça, başarılarıda artmaktadır (Wilson ve Narayan, 2016). Choi, Choi ve McAninch (2012). Fakat Çavdar (2015), TIMSS 2011 verilerini kullanarak yaptığı çalışmasında matematiğe ilişkin özgüven değişkenin matematik başarısını negatif yönde açıklayan bir değişken olarak bulunmuştur. Dördüncü sınıflar düzeyinde Türkiye'den TIMSS 2011 'e katılan öğrencilerin matematiğe ilişkin özgüven ölçek puan ortalamaları 10.3 olup üst sıralarda yer almaktadır. Almanya, Finlandiya, Hong Kong, Singapur ve Japonya'nın öğrencilerinin matematiğe ilişkin özgüvenleri daha düşük olmasına rağmen daha başarılı iken Kazakistan, İran, Suudi Arabistan, Umman gibi ülkeler ise daha yüksek özgüvene sahip olup daha başarısızdırlar (TIMSS Uluslararası Veritabanı, 2013). Ayrıca, Lee (2009) 41 OECD ülkesinin matematik yeterlik algısı, kendilik algısı, matematik kaygısı ve matematik başarıları açısından karşılaştırıldığı çalışmasında benzer sonuçlar elde edilmiştir. Yapılan çalışmanın sonuçlarına göre Asya ülkelerindeki öğrenciler düşük matematik yeterlik algıSı ve kendilik algısına sahip olmalarına rağmen matematikte daha başarılı iken, Avrupa ülkelerinde düşük özgüvene sahip öğrenciler daha başarılı olmaktadır. Elde edilen sonuçlara göre matematiğe ilişkin düşük özgüvene sahip öğrenciler matematikte daha başarılı olmaktadırlar. Daha farklı yapılan araştırmalarda da matematiğe ilişkin özgüvenin matematik başarısının önemli bir yordayıcısı olduğu bulunmuştur (Abal1-Öztürk ve Şahin, 2015; Ayan, 2014; Aydın, 2015; Çalışkan, 2014; Çavdar, 2015; Doğan ve Barış, 2010; Liu \& Meng, 2010; Sarı, Arıkan ve Yıldızoğlu, 2017; Stankov, Morony \& Lee, 2014). Matematiğe ilişkin özgüvenin matematik başarısında önemli bir yordayıcı olması nedeniyle, bu çalışmada da öğrencilerin TIMSS 2015 matematik başarılarındaki etkisi incelenmek amacıyla analize dahil edilmiştir.

Matematiği sevme ve matematiğe olan ilgi kavramlarıda matematik başarısında etkili olduğu düşünülen diğer duyuşsal değişkenler olarak çalışmamızda yer almaktadır. Önen (2018) öğrenci, öğretmen ve öğretimsel nitelikler açısından TIMMS 2015'e dayalı olarak öğrencileri 
sınıflandırdığı çalışmasında, matematiği sevme değişkenin öğrencilerin kümelere ayrılmasında en fazla katkı sağlayan değişken olarak bulmuştur. Dolayısıyla öğrencilerin matematiği sevmelerinin bireysel farklılıkların ortaya çıkarılmasında önemli bir değişken olduğu sonucuna ulaşabiliriz. Oral ve McGivney (2013), TIMSS 2011 sonuçlarının analizlerini yaptıkları çalışmalarında matematiği sevme ve öz güven değişkenlerinin matematik başarısı ile doğru orantılı olduğu sonucunu bulmuştur. Khine, Al-Mutawah ve Afari (2015), TIMSS 2011'e Birleşik Arap Emirlikleri'nin bir körfez eyaletinden katılan öğrencilerin matematik başarılarını incelediği çalışmalarında matematiği sevmenin öğrencilerin başarılarında anlamlı bir etkisi olduğu sonucuna ulaşmışlardır.

Öğrencilerin duyuşsal özelliklerinin yanısıra eğitim gördükleri okulların fiziki yapısı, eğitsel kaynakları ve ortamları da başarılarında etkili olmaktadır. TIMSS öğrenci anketi incelendiğinde, öğrencilerin okullarını nasıl algıladıkları ve okul ortamında öğretmenleri ve arkadaşları ile yaşadıkları ilişkilere ilişkin maddelerin yer aldığı görülmektedir. Okul ortamının matematik başarısına etkisinin incelendiği bir çok çalışmada okul ortamı boyutunda zorbalık değişkeni göz önüne alınmıştır. Öğrencilerin kendi aralarıdaki ilişkilerinde zorbalık diye nitelendirebileceğimiz davranışlar olarak ad takma, başkalarına vurma, tehdit etme, başkası hakkında yanlış bilgilerin yayılması vb. söyelenebilir (Jan ve Husain, 2015). Okul ortamında gerçekleşen zorbalık olayları öğrencilerin başarılarında önemli bir etki oluşturmaktadır (Akyüz, 2014; Buluç, 2014; Büyköztürk, Çakan, Tan ve Atar, 2014; Mohammadpour, 2012; Ölçüoğlu ve Çetin, 2016; Yavuz, Demirtaşlı, Yalçın ve Dibek, 2017). Buluç (2014) Türkiye' deki öğrencilerin TIMSS 2011 verilerini kullanarak yaptığı çalışmasında, Türkiye'deki okullarda öğrenim gören öğrencilerin okullarda şiddet-zorbalık davranışlarından şikayetçi olma oranının bir hayli yüksek olduğu sonucuna ulaşmıştır. Ayrıca şiddet-zorba davranışlarına göre matematik başarısının incelendiği Türkiye'de dahil olmak üzere tüm ülkelerde, neredeyse hiç bir bölgesinde bu tür olayların yer almadığı ülkelerin başarı puan ortalamalarının diğer ülkelerden daha yüksek olduğu sonucu bulunmuştur. Öğrencilerin matematik başarılarını etkilediği düşünülen okul ortamı değişkenleri olarak okula aidiyetlik, okulun akademik başarıya verdiği önem ve güvenli ve düzenli okul iklimi algısı yer alabilir. TIMSS 2011 öğrencilerin zorbalığa maruz kaldıkları ve bu durumunda matematik başarılarını olumsuz etkilediği düşünüldüğünde öğrencilerin okul ortamında zorbalığa uğramaları ile matematik başarılarının araştırlması önemli görülmektedir.

Öğrencilerin başarılarını etkileyen bir diğer önemli faktörde evde sahip oldukları eğitsel kaynaklarıdır. Gelişen teknoloji ile birlikte gelişmiş bir çok ülkede neredeyse her evde artık bilgisayar bulunmaktadır. Fakat Türkiye gibi gelişmekte olan ülkelerde ise bazı bölgelerde bilgisayara sahip olan öğrencilerin sayısı oldukça düşüktür. Bilgisayarın olduğı bazı evlerde de internet bağlantısı olmayabilir. Öğrencilerin sahip oldukları teknolojik imkanlar arttıkça başarılarıda artmaktadır. Bayar ve Bayar'ın (2013) yaptığı çalışmada öğrencilerin akademik başarısı ile evlerinde bulunan eğitsel kaynaklar arasında güçlü ve pozitif bir ilişkinin olduğu sonucu ortaya çıkmıştır. Yine yapılan bir çok benzer çalışmada da öğrencilerin matematik öğrenmelerini destekleyici ev kaynaklarının başarılarını arttırdığı görülmektedir (Akyüz, 2014; Akyüz ve Berberoğlu, 2010; Aydın, 2015; Henderson \& Mapp, 2012; Jeynes, 2005; Martin, Mullis, Gonzalez ve Chrostowski, 2004; Oral ve McGivney, 2013; Ölçüoğlu ve Çetin, 2016; Sarı vd., 2017; Skryabin, Zhang, Liu, ve Zhang, 2015; Y1lmaz ve Bindak, 2016). Özellikle teknolojik araçlara daha çok sahip olan öğrencilerin başarılarının arttığı göz önüne alınarak, TIMSS 2015'e katılan dördüncü ve sekizinci sınıf düzeyindeki öğrencilerin evlerinde sahip oldukları teknolojik araçlar ile matematik başarılarının incelenmesi önemli görülmektedir.

Literatür incelendiğinde, matematik başarısını etkileyen değişkenlerin öğrenci düzeyinde, okul düzeyinde ve hem öğrenci hem de okul düzeyinde ele alındığı görülmektedir. Bu çalışmada 
ise öğrencilerin duyuşsal özelliklerinden matematiği sevme, matematiğe olan ilgi ve matematiğe ilişkin özgüven değişkenleri ile ev ortamı ve okul ortamı değişkenlerinin matematik başarısı üzerindeki etkisi incelenmiştir. Öğrencilerin başarılarında tek bir değişkenin etkili olmadığı birden fazla değişkenin başarıyı açıklamada önemli etkilerinin olduğu görülmektedir. TIMSS 2015 sonuçlarına göre Türkiye matematik alanında dördüncü sınıflarda 36. sekizinci sınıflarda ise 24 . sırada bulunmaktadır (Yücel ve Karadağ, 2016). TIMSS 2011 sonuçları ile karşılaştırıldığında Türkiye'nin başarı seviyesi artmış gözükmektedir. Mateamatik başarısı üzerinde önemli olan değişkenlerin birlikte ele alınıp incelenmesi ile matematik başarısı üzerinde etkili olan değişkenlerin belirlenmesi önemli görülmektedir. Bu doğrultuda bu çalışmada matematiği sevme, matematiğe olan ilgi ve matematiğe ilişkin özgüven değişkenleri ile ev ortamı ve okul ortamı değişkenlerinin matematik başarısını açıklamaya ilişkin bir model kurulmuştur. Kurulan modelin matematik başarısı ile ilişkisi yapısal eşitlik modellemesi ile incelenmiştir.

\subsection{Araştırmanın Amacı ve Önemi}

Matematik insanlık tarihinin her döneminde çok önemli bir yer tutan bir bilimdalı olmuştur. Dünyada var olan birçok durum ve olayın açıklaması matematik bilimi ile yapılmıştır. Matematik sadece kendi içinde bir bilim olmayıp, diğer bilim alanları ile de etkileşimli olduğu için, matematik alanında gelişimler diğer alanlardaki gelişimleri de etkilemektedir. Bu nedenle matematik eğitimi, ülkelerin eğitim sistemlerinde çok önemli bir yere sahiptir. Ayrıca başka bilimlerle olan etkileşimi sonucu günümüzdeki öneminin yanında, gelecekteki önemini de sürdüreceği ve modern bilimin insanlık hizmetine sunduğu pek çok durumda başrol oynayacağı belli olan alanlardan biridir. Matematiğin ülkelerin gelişimleri açısından çok önemli yer tutması nedeni ile birçok ülke yaptıkları araştırmalarla TIMSS, PIRLS ve PISA gibi uluslararası sınavlarda öğrencilerinin matematikteki başarı ve başarısızlıklarının nedenlerini incelemekte ve gerekli önlemlerin alınmasına çalışmaktadırlar.

Dördüncü ve sekizinci sınıf düzeyinde Türkiye'den öğrencilerin de katıldığı TIMSS'de Türkiye'nin başarısı bir önceki sınav sonuçlarına göre artmakla birlikte yine de öğrencilerin matematik başarılarının ülkeler arası ortalamanın altında kaldığı görülmektedir (Mullis, Martin, Foy ve Arora 2012). Bu durum matematik başarısına etki eden değişkenlerin daha çok araştırılmasına ve araştırma sonuçlarına göre başarıyı artıracak çözüm yollarının geliştirilmesine yol açmaktadır.Yapılan çalışmalar öğrencilerin farklı duyuşsal özelliklerinin, öğrenim gördükleri okul ortamının ve yaşadıkları ev ortamının başarıları üzerinde etkili olduğunu göstermektedir (Çavdar, 2015; Markey, 2009; Ölçüoğlu, 2015; Özer ve Anıl, 2011).

$\mathrm{Bu}$ araştırma ile TIMSS 2015 Türkiye dördüncü ve sekizinci sınıf öğrencilerine ilişkin matematiği sevme, matematiğe olan ilgi, matematiğe ilişkin özgüven, okul ortamı ve ev ortamı özellikleri ile matematik başarıları arasındaki ilişkilerinin yapısal eşitlik modeli ile incelenmesi amaçlanmıştır. Bu amaç doğrultusunda, öğrencilerin matematiği sevme, matematiğe olan ilgi ve matematiğe ilişkin özgüven gibi duyuşsal özellikleri ile birlikte ev ortamı ve okul ortamı değişkenleri ele alınarak bir yapısal eşitlik modeli kurulmuştur. Kurulan yapısal eşitlik modeli hem dördüncü hem de sekizinci sınıf TIMSS 2015 verisi üzerinden test edilmiştir.

Modelde öğrencilerin duyuşsal özellikleri ile ev ortamı ve okul ortamı özelliklerinin birlikte ele alınması ile bu çalışmanın, öğrencilerin matematik başarılarını artırma konusunda eğitimcilere ve ailelere yol göstereceği düşünülmektedir. Ayrıca bu araştırmanın sonuçlarının, matematik başarısı ile ilgili yapılacak diğer çalışmalara teorik ve pratik bilgiler sunması beklenmektedir. 
TIMSS 2015 matematik başarısını etkileyen değişkenlerin yapısal eşitlik modeli ile incelenmesi

\section{Yöntem}

\subsection{Araştırmanın Modeli}

Matematik başarısı ile ilgili değişkenlerin incelendiği bu araştırmanın türü ilişkisel tarama modelidir. İlişkisel araştırmalarda var olan durum betimlenirken, değişkenlerin birbirleriyle ne şekilde ilişskili olduğu da incelenmektedir (Büyüköztürk vd., 2014).

\subsection{Evren ve Örneklem}

Araştırmanın evrenini Türkiye'de öğrenim gören dördüncü ve sekizinci sınıf öğrencileri oluşturmaktadır. Araştırmanın örneklemi ise iki aşamalı tabakalı örnekleme yönteminin kullanıldığı TIMSS 2015 Türkiye örneklemidir. Örneklem seçiminin birinci aşamasında okullar, ikinci aşamada ise bu okullarda yer alan sınıflar seçilmiştir. Okulların seçiminde okulların sistematik seçkisiz örneklem yöntemi kullanılmıştır. İkinci aşamada da seçilen okullarda yer alan bütün sınıfların eşit seçilme şanslarının olduğu sistematik seçkisiz örneklem yöntemi kullanılarak öğrenciler sçilmiştir (LaRoche, Joncas ve Foy, 2015). TIMSS 2015'e Türkiye'den dördüncü sınıf düzeyinde toplam 260 okul, sekizinci sınıf düzeyinde toplam 238 okul katılmıştır. Öğrenci anketleri ve başarı testleri, dördüncü sınıf düzeyinde toplam 6456 öğrenciden, sekizinci sınıf düzeyinde ise toplam 6079 öğrenciden elde edilmiştir.

\subsection{Veri Toplama Araçları}

Araştırmada veri toplama araçlarını, TIMSS 2015'e katılan dördüncü ve sekizinci sınıf öğrencilerine uygulanan öğrenci anketleri ve matematik başarı testleri oluşturmaktadır. Araştırmanın amacı doğrultusunda, öğrenci anketinde yer alan matematiği sevme, matematiğe olan ilgi, matematiğe ilişkin özgüven değişkenleri ile birlikte öğrencilerin ev ortamlarını ve okul ortamlarını yansıtan maddeler göz önüne alınmıştır. Matematik bilişsel testi ise her iki sınıf düzeyinde de (dördüncü ve sekizinci sınıf) yaklaşık yarısı çoktan seçmeli, yarısı uzun/kısa cevaplı maddelerden oluşmaktadır. Fen ve matematik bilişsel testlerinin yer aldığı TIMSS 2015'te başarı testindeki maddeler 14'ü fen ve 14'ü matematik olmak üzere toplam 28 bloktan oluşmaktadır. Bloklar 14 test kitapçığına, ikisi fen ve ikisi matematik olmak üzere dörderli bloklar halinde dağıtılmıştır. Test eşitleme yapılabilmesi için fen ve matematik alanlarındaki her iki bloktan biri iki kitapçık arasında ortaktır. TIMSS'te öğrencilerin başarılarını gösteren beş adet değişken bulunmaktadır. TIMSS verisinde "olası değerler" (plausible values) şeklinde ifade edilen bu değerler veya bu değerlerin ortalaması bireysel öğrenci başarısının bir göstergesi değildir (Yıldırım, Yıldırım, Ceylan ve Yetişir, 2013, s. 8). Bu araştırmada da öğrencilerin matematik başarı performanslarını gösteren bu beş adet olası değer, matematik başarı puanı gizil değişkeni oluşturularak, bu gizil değişkeni ölçmeye yönelik olarak kullanılan göstergeler olarak yer almıştır.

Araştırma kapsamında, öğrencilerin matematik başarısı ile ilişkili olduğu düşünülen matematiği sevme, matematiğe olan ilgi, matematiğe ilişkin özgüven, ev ortamı ve okul ortamı değişkenlerine ilişkin maddeler öğrenci anketinden elde edilmiştir. Öğrenci anketinde yer alan maddelerde "ASB...."ile başlayan maddeler dördüncü sınıflara ilişkin maddeleri gösterirken, "BSB..."ile başlayan maddeler sekizinci sınıflara ilişkin maddelerdir.

Öğrenci anketinde yer alan matematiği sevme, matematiğe olan ilgi ve matematiğe ilişkin özgüven boyutlarındaki tepki kategorileri 1 "Hiç katılmıyorum" u, 2 "Katılmıyorum" u, 3 "Az katılıyorum" u, 4 "Çok katılıyorum" u ifade edecek şekilde kodlanmıştır. Matematiği sevme değişkeni matematik öğrenirken eğleniyorum, matematiği seviyorum, matematikteki problemleri 
severim, matematik derslerini dört gözle beklerim ve en favori dersim matematiktir şeklinde beş maddeden oluşmaktadır. Öğrencinin matematikten almış olduğu yüksek puan, matematiği çok sevdiğini gösterir. Matematiğe olan ilgi değişkeni anlşılır cevaplar veririm, öğretmenim iyi açıklamalarda bulunur, öğretmenime öğrendiğimi gösteririm, matematikte daha iyi olmaya çalışırım ve öğretmenimi dinlerim şeklinde beş maddeden oluşmaktadır. Ölçekten alınan puan arttıkça öğrencinin matematiğe olan ilgiside artmaktadır. Matematiğe ilişkin özgüven değişkeni ise diğer öğenciler ile karşılaştırıldığında matematik bana daha zor geliyor, sadece matematikte iyi değilim, matematik diğer derslerden daha zor ve matematik kafamı karıştırıyor şeklinde dört maddeden oluşmaktadır. Bu ölçekteki maddeler olumsuz ifadeler içerdiği için ters kodlama yapılmıştır. Bu nedenle öğrencinin yüksek puan alınması matematiğe ilişkin özgüvenin yüksek olduğunu göstermektedir.

Okul ortamı değişkeni altındaki maddelerin cevap kategorilerinde 1 "Asla" y1, 2 "Yılda birkaç kez” i, 3 “ Ayda bir ya da iki kez” i ,4 "Haftada en az bir kez" i ifade etmektedir. Buna göre öğrencilerin okullarındaki zorbalık düzeylerinin belirlenmeye çalışıldığı bu ölçekteki maddeler; kendisi hakkında yalan bilginin yayılması, şiddete uğrama, zorla bir şey yapmaya mecbur bırakılma, kendisini utandıracak bilginin yayılması ve tehdit edilme şeklindedir. Okul ortamı değişkenin alınan puan arttıkça, öğrencilerin zorbalığa maruz kalma düzeyleri de artmaktadır.

Öğrencilerin evde sahip oldukları teknolojik kaynakların belirlenmeya çalışıldığı ev ortamı değişkeninde, bilgisayara sahip olma, bilgisayarı paylaşma, çalışma masasına sahip olma, internet bağlantısı olma durumu ve ülkeye özgü değerdir. Burada maddelerin kategorileri 1 "Evet" i, 2 "Hayır" 1 ifade edecek şekilde kodlanmıştır. Ev ortamı ölçeğinden alınan yüksek puan öğrencinin daha fazla kaynağa sahip olduğunu göstermektedir.

Araştırmada yer alan değişkenlerin faktör yapılarını belirlemek için her bir değişken için çımlayıcı Faktör Analizi (AFA) yapılmıştır. AFA' ya başlamadan önce, veri yapısının faktör analizi uygunluğuna bakmak için Kaiser- Meyer- Olkin (KMO) katsayısı ve Barlett küresellik testi incelenmiştir. KMO katsayı değerinin 0,60’tan yüksek çıkması ve Barlett küresellik testinin kikare değerinin anlamlı çıkması çalışılan örneklemin açımlayıcı faktör analizi için uygun/yeterli olduğuna işaret etmektedir (Çokluk, Şekercioğlu, Büyüköztürk, 2013). Yapılan AFA'da faktör sayısına sınırlama konulmadan temel bileşenler analizi uygulanmış ve herhangi bir döndürme işlemi yapılmamıştır.

Dördüncü sınıflar için yapılan AFA sonuçlarında, matematiği sevme değişkeni için elde edilen KMO değeri 0,80'dir ve Barlett küresellik testinin ki-kare değeri manidar bulunmuştur $(\mathrm{p}<0,05)$. Elde edilen bu sonuçlara göre, örneklemin faktör analizi yapabilmek için yeterli olduğu ve verilerin faktör analizine uygun olduğu düşünülmüştür. Temel bileşenler analizi sonucunda öz değeri 2,96 olan tek faktör ortaya çıkmıştır. Bu tek faktörün açıkladığı varyans oranı ise \% 59'dur. Tek faktör beş madde ile temsil edilmiştir ve maddelerin faktör yük değerleri de 0,70 ile 0,86 arasındadır. Matematiğe olan ilgi değişkeni için yapılan AFA sonuçlarında ise elde edilen KMO değeri 0,70'dir ve Barlett küresellik testinin ki-kare değeri manidar bulunmuştur $(\mathrm{p}<0,05)$. Dolayısıyla örneklemin faktör analizi yapabilmek için yeterli olduğu ve verilerin faktör analizine uygun olduğu görülmüştür. Uygulanan temel bileşenler analizi sonucunda öz değeri 1,76 olan tek faktör ortaya çıkmış ve tek faktör varyansın \% 35'ni açıklamıştır. Tek faktöre yüklenen maddelerin faktör yük değerleri de 0,36 ile 0,68 arasında değişmektedir. Matematiğe ilişkin özgüven değişkeni için yapılan AFA sonuçlarında ise elde edilen KMO değeri 0,77'dir ve Barlett küresellik testinin ki-kare değeri manidar bulunmuştur $(\mathrm{p}<0,05)$. Dolayısıyla örneklemin faktör analizi yapabilmek için yeterli olduğu ve verinin faktör analizine uygun olduğu görülmüştür. Uygulanan temel bileşenler analizi sonucunda öz değeri 2,42 olan tek faktör ortaya çıkmış ve tek faktör varyansın \% 60 ‘nı açıklamaktadır. Ayrıca tek faktör altında yer alan maddelerin faktör yük değerleri de 0,76 ile 
TIMSS 2015 matematik başarısını etkileyen değişkenlerin yapısal eşitlik modeli ile incelenmesi

0,79 arasındadır. Dördüncü sınıflarda okul ortamı değişkeni için yapılan AFA sonuçlarında ise KMO değeri 0,81 olarak bulunmuş ve Barlett küresellik testi de manidar çıkmıştır $(\mathrm{p}<0,05)$. Tek faktörün oluştuğu AFA sonucuna göre açıklanan varyans \% 49 iken, maddelerin faktör yük değerleri 0,66 ile 0,75 arasında değişmektedir. Dördüncü sınıfların ev ortamı değişkeni için yapılan AFA sonucunda ise KMO değeri 0,72 bulunurken, Barlett küresellik testi de manidar çıkmıştır ( $\mathrm{p}<0,05)$. Tek faktörün açıkladığı varyans \%40 iken, faktör yük değerleri de 0,53 ile 0,71 arasında değişmektedir.

Sekizinci sınıflar için yapılan AFA sonuçlarında ise, matematiği sevme değişkeni için elde edilen KMO değeri 0,88'dir ve Barlett küresellik testinin ki-kare değeri manidar bulunmuştur $(\mathrm{p}<0,05)$. Elde edilen bu sonuçlara göre, örneklemin faktör analizi yapabilmek için uygun olduğu görülmüştür. Temel bileşenler analizi sonucunda öz değeri 3,87 olan tek faktör ortaya çıkmıştır. Bu tek faktörün açıkladığı varyans oranı ise \% 77'dir. Tek faktör beş madde ile temsil edilmiştir ve maddelerin faktör yük değerleri de 0,86 ile 0,91 arasındadır. Matematiğe olan ilgi değişkeni için yapılan AFA sonuçlarında ise elde edilen KMO değeri 0,87'dir ve Barlett küresellik testinin kikare değeri manidar bulunmuştur $(\mathrm{p}<0,05)$. Dolayısıyla örneklemin faktör analizi yapabilmek için yeterli olduğu ve verilerin faktör analizine uygun olduğu görülmüştür. Uygulanan temel bileşenler analizi sonucunda öz değeri 3,39 olan tek faktör ortaya çıkmış ve tek faktör varyansın \% 68'ini açıklamıştır. Tek faktöre yüklenen maddelerin faktör yük değerleri de 0,79 ile 0,84 arasında değişmektedir. Matematiğe ilişkin özgüven değişkeni için yapılan AFA sonuçlarında ise elde edilen KMO değeri 0,80'dir ve Barlett küresellik testinin ki-kare değeri manidar bulunmuştur $(\mathrm{p}<0,05)$. Dolayısıyla örneklemin faktör analizi yapabilmek için yeterli olduğu ve verilerin faktör analizine uygun olduğu görülmüştür. Uygulanan temel bileşenler analizi sonucunda öz değeri 2,81 olan tek faktör ortaya çıkmış ve tek faktör varyansın \% 70'ini açıklamaktadır. Ayrıca tek faktör altında yer alan maddelerin faktör yük değerleri ise 0,80 ile 0,86 arasındadır. Sekizinci sınıflar okul ortamı değişkeni için yapılan AFA sonuçlarında ise KMO değeri 0,79 olarak bulunmuş ve Barlett küresellik testi ki kare değeri manidar bulunmuştur $(p<0,05)$. Tek faktörün oluştuğu AFA sonucuna göre açıklanan varyans \%50 iken, faktör yük değerleri 0,66 ile 0,79 arasında değişmektedir. Sekizinci sınıflar ev ortamı değişkeni için yapılan AFA sonucunda ise KMO değeri 0,75 iken, Barlett küresellik testi manidar bulunmuştur $(\mathrm{p}<0,05)$. Tek faktörün açıkladığ 1 varyans $\% 43$ iken, faktöre yüklenen maddelerin faktör yük değerleri de 0,57 ile 0,73 arasında değişmektedir.

Ayrıca AFA sonrasında her bir faktör için güvenirlik katsayısı hesaplanmıştır. AFA sonuçları dikkate alındığında her bir faktör altındaki maddelerin faktör yük değerlerinin birbirinden farklı olduğu ve maddelere ilişkin ortalama ve standart sapma değerlerinin de eşit olmadiğ bulunmuştur. Bu doğrultuda bu ölçümlerin güvenirliği için McDonald'ın $\omega$ katsayısı kullanılmıştır (Yurdugül, 2006). McDonald'ın $\omega$ katsayısını hesaplamak için Doğrulayıcı Faktör Analizi (DFA) yapılmıştır. McDonald'ın $\omega$ katsayısının hesaplanmasında her bir madde için elde edilen standartlaştırılmamış faktör yükleri ile standartlaştırılmamış hatalar kullanılmıştır. Her iki sınıf düzeyindeki değişkenler için elde edilen $\omega$ güvenirlik katsayıları Tablo 1'de verilmiştir. 
Tablo 1. Araştırmadaki Ölçümler için Elde Edilen McDonald's $\omega$ Güvenirlik Katsayıları

\begin{tabular}{lccccc}
\hline & $\begin{array}{c}\text { Matematiği } \\
\text { sevme }\end{array}$ & $\begin{array}{c}\text { Matematiğe } \\
\text { olan ilgi }\end{array}$ & $\begin{array}{c}\text { Matematiğe } \\
\text { ilişkin özgüven }\end{array}$ & $\begin{array}{c}\text { Okul } \\
\text { ortamı }\end{array}$ & $\begin{array}{c}\text { Ev } \\
\text { ortamı }\end{array}$ \\
\hline Dördüncü Sınıf & 0,95 & 0,97 & 0,87 & 0,86 & 0,88 \\
Sekizinci Sınıf & 0,96 & 0,92 & 0,89 & 0,84 & 0,89 \\
\hline
\end{tabular}

Tablo 1'deki güvenirlik katsayıları incelendiğinde, dördüncü sınıf düzeyinde elde edilen ölçümlere ilişkin hesaplanmış Mcdonald'ın $\omega$ güvenirlik katsayılarının $\omega=0,86$ ve $\omega=0,97$ arasında değiştiği, sekizinci sınıf düzeyinde elde edilen güvenirlik katsayılarının ise $\omega=0,84$ ve $\omega$ $=0,96$ arasında değiștiği görülmektedir. Mcdonald's $\omega$ güvenirlik katsayılarının 0,80 'den yüksek olması maddelerden elde edilen puanların güvenirliğinin yüksek olduğunu göstermektedir.

Açımlayıcı faktör analizleri sonucunda değişkenler için elde edilen faktörlerin ve faktörlere ilişkin göstergelerin ölçülen özelliğin iyi birer temsilcisi olduğu ve ölçümlerin güvenilir olduğu sonucuna varılmıştır. AFA sonuçlarına göre elde edilen faktörler göz önüne alınarak ilişkisel bir model olan yapısal eşitlik modellemesi (YEM) kurulmuştur.

\subsection{Verilerin Analizi}

Verinin analizi için SPSS 21.0 ve LISREL 8.8 programları kullanılmıştır. SPSS 21.0 ile analizler için gerekli olan sayıltıların kontrolü yapıldıktan sonra, LISREL 8.8 programı ile de kurulan yapısal eşitlik modeli test edilmiştir.

Analizlere başlamadan önce veri seti hazır hale getirilmiştir. Veri setinin hazır hale getirilmesi için kayıp veri analizi, uç değerlerin tespit edilmesi, çok değişkenli normallik, doğrusallık ve çoklu bağlantı sorunu sayıltıları incelenmiştir. İlk olarak kayıp veri analizi için dördüncü ve sekizinci sınıflara uygulanan her bir anket için ayrı ayrı betimsel istatistikler incelenmiş ve kayıp verinin miktarı ve örüntüsü için Little's MCAR (Missing Completely at Random) testi yapılmıştır. Betimsel istatistiklere göre dördüncü sınıflara uygulanan öğrenci anketinde dokuz kişi anket sorularının hiçbirine cevap vermediği için analiz dışı bırakılmıştır. Uygulanan Little's MCAR testi sonucuna göre, dördüncü sınıf anketindeki veride kayıp veri miktarı \%5'ten az olduğu için liste bazında veri silme işlemi uygulanmıştır (Tabachnick ve Fidell, 2013, s. 63). Benzer şekilde sekizinci sınıflara uygulanan anketteki veride de 23 kişi anketteki hiçbir soruya cevap vermediği için analiz dışı bırakılmıştır. Sekizinci sınıflardaki veride de kayıp veri miktarı \% 5 'ten az olduğu için liste bazında veri silme işlemi uygulanmıştır.

Kayıp veri silme işleminden sonra tek ve çok değişkenli uç değerlerin tespit edilmesine geçilmiştir. Tek değişkenli uç değerlerin tespiti için değişkenlerin mutlak $\mathrm{z}$ değerleri hesaplanmıştır. Hesaplanan z değerlerinden mutlak değeri 4'den büyük olan değerler tek değişkenli uç değer olarak değerlendirilmiş ve analiz dışı bırakılmıştır (Harrington, 2009, s.42). Böylece dördüncü ve sekizinci sınıfların veri setinde mutlak z değeri 4'ten büyük olan değerler silinmiştir. Çok değişkenli uç değerlerin tespitinde ise Mahalanobis uzaklığı hesaplanmıştır. Mahalonobis testinde serbestlik derecesi olarak değişken sayısı alınmış ve dördüncü sınıflar için kritik ki-kare değeri 58,301'den büyük olan 421 kişinin verisi silinirken sekizinci sınıflar da 353 kişinin verisi çok değişkenli uç değer olarak kabul edilmiş ve analiz dışı bırakılmıştır. Kayıp veri uç değerlerin silinmesinden sonra analizler dördüncü sınıflar için 4,471, sekizinci sınıflar için ise 5,198 öğrenci üzerinden yürütülmüştür.

Tek değişkenli ve çok değişkenli normallik sayıltıları da sırası ile incelenmiştir. Tek değişkenli normallik sayıltısı için dördüncü ve sekizinci sınıflar anketlerindeki her bir değişkenin 
çarpıklık ve basıklık katsayıları, bunlara ilişkin standart hatalara bölünerek $p<0,05$ anlamlılık düzeyinde incelenmiştir. Buna göre 1,96'dan büyük değerlerin tek değişkenli normallik sayıltısını karşılamadığı yorumu yapılmıştır (Harrington, 2009, s. 42). Ayrıca çok değişkenli normallik için örneklem büyüklüğü de dikkate alınarak dağılımın şekline bakılmıştır. Çok değişkenli normalliğin de sağlanmadığı görülmüştür. Tek değişkenli ve çok değişkenli normallik sayıltılarının karşılanmaması nedeni ile yapısal eşitlik modeli analizlerinde kestirim yöntemi olarak robust en çok olabilirlik kestirim yöntemi (RMLE) kullanılmış ve asimptotik kovaryans matrisleri oluşturulmuştur.

Doğrusallık sayıltısı için her bir faktörde saçılım grafikleri incelenmiştir. Elde edilen sonuçlara göre doğrusallık sayıltısının karşılandığı görülmüştür. Çoklu bağlantı sorunu için ise modelde yer alan değişkenler arasındaki korelasyon değerlerine bakılmıştır. İki değişken çifti arasındaki korelasyon değerinin $r>0,90$ olması çoklu bağlantı sorununa işaret etmektedir (Çokluk, Şekercioğlu ve Büyüköztürk, 2013). Buna göre, korelasyon değeri 0,90'nın üstünde bulunan değişken çifti bulunmadığı için çoklu bağlantı sorununa rastlanmamıştır. Sayıltıların kontrol edilmesinden sonra YEM analizine geçilmiştir.

YEM analizi, araştırmacı tarafından gözlenen ve gizil değişkenler arasındaki ilişkiler tanımlanarak oluşturulan bir modelin örneklemden elde edilen veriye uyumunun incelenmesini sağlayan istatistiksel bir modelleme tekniğidir. Yapısal eşitlik modellemesi gözlenen ve gizil değişkenler arasındaki ilişkinin incelenmesine olanak sağlayan bir analiz tekniğidir (Preacher, Zyphur ve Zhang, 2010). YEM, faktörlerin çoklu regresyon ile açımlayıcı faktör analizinin birleşiminden oluşmaktadır (Tabachnick ve Fidell, 2007, s. 676). YEM; ölçme modelini (göstergeler ve gizil değişkenler arasındaki ilişkileri) test etmede kullanılan ve gizil değişkenler arasındaki ilişkilerin yer aldığı yapısal modeli inceleyen geniş bir analiz topluluğudur (Harrington, 2009, s. 11). YEM‘de ilk önce ölçme modelinin model veri uyumu incelenir, daha sonra yapısal modelin test edilmesine geçilir.

$\mathrm{Bu}$ araştırmada da dördüncü ve sekizinci sınıflar için kurulan modelde yer alan her bir ölçme modeli için DFA yapılmıştır. Yapılan DFA'da model veri uyumunu değerlendirmek için göz önüne alınan uyum indeksleri şunlardır: $\chi 2 / s d$, RMSEA, SRMR, GFI, CFI ve NNFI'dır.

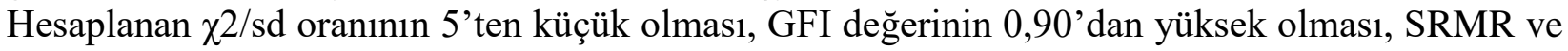
RMSEA değerlerinin ise 0,05 dan düşük çıkması, model - veri uyumu için ölçüt değerler olarak kabul edilir (Jöreskog ve Sörbom, 1993; Marsh ve Hocevar, 1988). Bununla birlikte, GFI'nin 0,80 ve 0,80'den büyük çıkması ile SRMR ve RMSEA değerlerinin 0,10'dan düşük çıkması, model veri uyumu için kabul edilebilir alt sınırlar olarak verilmektedir (Anderson ve Gerbing, 1984; Cole, 1987; Marsh, Balla, ve McDonald, 1988). Karşılaştırmalı uyum indeksleri olan CFI ve NNFI değerlerinin ise 0,95 'in üzerinde olması çok iyi bir uyumu, 0,90-0,95 olması ise kabul edilebilir bir uyumu göstermektedir (Sümer, 2000). Kurulan ölçme modellerine ilişkin uyum indeksleri ( $\chi 2$ /sd, RMSEA, SRMR, GFI, CFI ve NNFI), standartlaştırılmış faktör yük değerleri ve hata varyansları dördüncü sınıflar için Tablo 2’de, sekizinci sınıflar için Tablo 3'de verilmiştir. 
Tablo 2. Dördüncü Sınıf Düzeyi için Doğrulayıcı Faktör Analizi Sonuçları

\begin{tabular}{ccccccccc}
\hline Değişkenler & $\chi \mathbf{2}(\mathbf{s d})$ & RMSEA & SRMR & CFI & NNFI & GFI & $\begin{array}{c}\text { Faktör } \\
\text { yükleri }\end{array}$ & $\begin{array}{c}\text { Hata } \\
\text { varyansları }\end{array}$ \\
\hline Matematiği sevme & $5,92(5)$ & 0,00 & 0,01 & 1,00 & 1,00 & 0,99 & $0,75-1,00$ & $0,00-0,44$ \\
Matematiğe olan ilgi & $10,25(5)$ & 0,01 & 0,02 & 1,00 & 1,00 & 0,98 & $0,56-0,76$ & $0,50-0,68$ \\
Matematiğe ilişkin özgüven & $83,33(2)$ & 0,09 & 0,03 & 0,99 & 0,98 & 0,97 & $0,78-0,81$ & $0,35-0,40$ \\
Okul Ortamı & $15,37(5)$ & 0,02 & 0,01 & 1,00 & 1,00 & 0,99 & $0,67-0,86$ & $0,26-0,55$ \\
Ev Ortamı & $44,47(4)$ & 0,04 & 0,03 & 0,99 & 0,99 & 0,98 & $0,48-0,74$ & $0,45-0,77$ \\
\hline
\end{tabular}

Tablo 2 incelendiğinde, uyum indeks değerlerinin [ $\chi 2$ (sd), RMSEA, SRMR, GFI, CFI ve NNFI] ölçüt alınan değerleri karşıladıkları görülmüştür. Ayrıca her bir ölçme modelindeki faktör yük değerleri, $\lambda=0,48$ ile 1,00 arasında değişmektedir. Bu değerlerin $\lambda=0,30$ ve üzerinde olmas1 bu maddelerin ölçülen özelliğin iyi birer temsilcisi olduğunu göstermektedir (Çokluk, Şekercioğlu ve Büyüköztürk, 2013, s.134). Ayrıca maddelere ilişkin hata (özgül) varyanslar ise $\varepsilon=0,00$ ve 0,77 arasında değişim göstermektedir. Bu değerlerin de 0,90'dan küçük değerler olması kabul edilebilir hata miktarlarına işaret etmektedir. Dolayısıyla dördüncü sınıflar için kurulan modelde, her bir gizil değişken için model veri uyumunun sağlandığı ve maddelerin ilgili gizil değişkenlerin iyi birer temsilcisi oldukları sonucuna ulaşılır. Sekizinci sınıflar için elde edilen ölçme modeli sonuçları da Tablo 3 'te gösterilmektedir.

Tablo 3. Sekizinci Sınıf Düzeyi için Doğrulayıcı Faktör Analizi Sonuçları

\begin{tabular}{ccccccccc}
\hline Değişkenler & \multicolumn{1}{c}{ (sd) } & RMSEA & SRMR & CFI & NNFI & GFI & $\begin{array}{c}\text { Faktör } \\
\text { yükleri }\end{array}$ & $\begin{array}{c}\text { Hata } \\
\text { varyansları }\end{array}$ \\
\hline Matematiği sevme & $132,22(4)$ & 0,08 & 0,01 & 1,00 & 0,99 & 0,96 & $0,85-0,96$ & $0,09-0,27$ \\
Matematiğe olan ilgi & $139,33(5)$ & 0,07 & 0,02 & 1,00 & 0,99 & 0,96 & $0,81-0,87$ & $0,24-0,35$ \\
Matematiğe ilişkin özgüven & $13,22(1)$ & 0,05 & 0,00 & 1,00 & 1,00 & 1,00 & $0,71-0,90$ & $0,19-0,50$ \\
Okul Ortamı & $39,15(5)$ & 0,03 & 0,02 & 1,00 & 1,00 & 0,98 & $0,68-0,88$ & $0,23-0,54$ \\
Ev Ortamı & $48,62(4)$ & 0,05 & 0,03 & 1,00 & 0,99 & 0,98 & $0,51-0,83$ & $0,31-0,74$ \\
\hline
\end{tabular}

Tablo 3 incelendiğinde, uyum indeks değerlerinin $\chi 2$ (sd), RMSEA, SRMR, GFI, CFI ve NNFI kabul edilen ölçüt değerlerini karşıladıkları görülmüştür. Ayrıca her bir ölçme modelindeki faktör yük değerleri, $\lambda=0,51$ ile 0,96 arasında değişmektedir. Bu değerlerin $\lambda=0,30$ ve üzerinde olması bu maddelerin ölçülen özelliğin iyi birer temsilcisi olduğunu göstermektedir. Ayrıca maddelere ilişkin hata (özgül) varyansları ise $\varepsilon=0,09$ ile 0,74 arasında değişim göstermektedir. Bu değerlerin de 0,90'dan küçük değerler olması kabul edilebilir hata miktarlarına işaret etmektedir. Dolayısıyla sekizinci sınıflar için kurulan modelde, her bir gizil değişken için model veri uyumunun sağlandığı ve maddelerin ilgili gizil değişkenlerin iyi birer temsilcisi oldukları sonucuna ulaşılır.

Her bir ölçme modelinin veriye uyumu sağlandıktan sonra dördüncü ve sekizinci sınıflar için kurulan yapısal eşitlik modeline geçilmiştir. Yapısal eşitlik modelinde öğrencilerin matematiği sevme, matematiğe olan ilgi, matematiğe ilişkin özgüven gibi duyuşsal özellikleri ile okul ortamı, ev ortamı değişkenlerinin matematik başarılarına etkisi incelenmektedir. 
TIMSS 2015 matematik başarısını etkileyen değişkenlerin yapısal eşitlik modeli ile incelenmesi

\section{Bulgular}

Dördüncü sınıflar için kurulan yapısal modelin veriye uyumunu değerlendirmek için elde edilen uyum indeksleri Tablo 4'te gösterilmiştir.

\section{Tablo 4. Dördüncü Sınıflar için Kurulan Yapısal Eşitlik Modelinin Uyum Índeksleri}

\begin{tabular}{lcccccc}
\hline & $\chi^{2}(\boldsymbol{s d})$ & RMSEA & SRMR & CFI & NNFI & GFI \\
\hline Yapısal Model & $4241,35(362)$ & 0,05 & 0,05 & 0,98 & 0,97 & 0,90 \\
\hline
\end{tabular}

Tablo 4 incelendiğinde dördüncü sınıflar için kurulan yapısal modelin uyum indeks değerlerinin ( $\chi^{2}$ (sd), RMSEA, SRMR, CFI, NNFI, GFI) kritik değerleri karşıladıkları görülmektedir. Yapısal modelin veriye uyumu sağlandığ1 görülmüştür. Yapısal modelin veriye uyumu sağlandıktan sonra, yapısal eşitlik modeline ilişkin yol diyagramı Şekil 1'de gösterilmiştir.

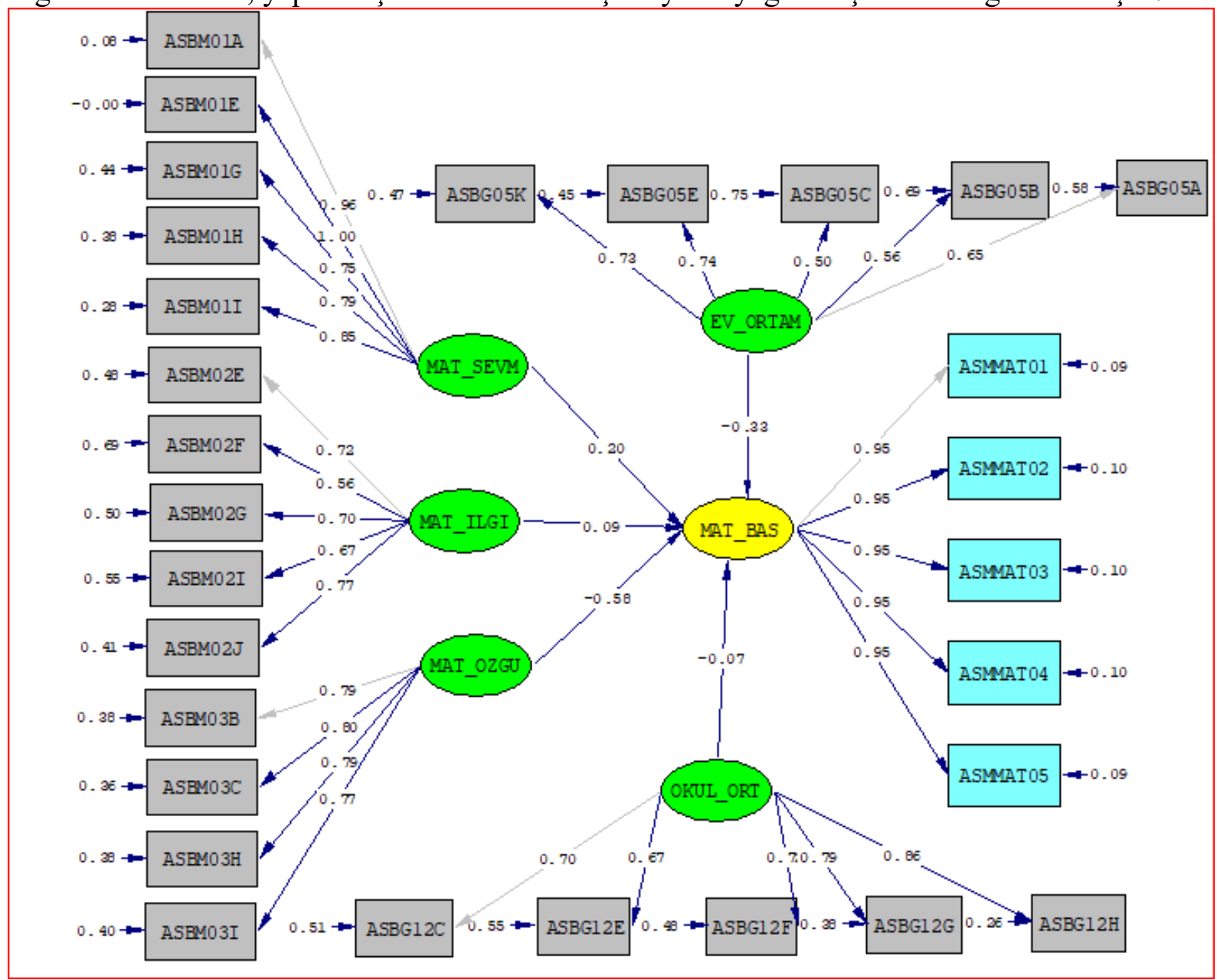

Şekil 1. Dördüncü Sınıflar İçin Kurulan Yapısal Eşitlik Modeline İlişkin Yol Diyagramı

Şekil 1'de, dördüncü sınıflar için kurulan yapısal eşitlik modeline ilişkin elde edilen yol katsayıları, standartlaştırılmış faktör yük değerleri ve standartlaştırılmış hata değerleri gösterilmiştir. Standartlaştırılmış faktör yük değerleri incelendiğinde, hepsi 0,30'dan büyük, standartlaştırılmış hata değerleri 0,90'dan küçük olduğu için madde atılmamıştır. Yapısal modelde yer alan yol katsayıları (standartlaştırılmış katsayılar) ve etki büyüklüklerine ilişkin elde edilen değerler Tablo 
5 'te gösterilmiştir. Modelde, standart yol katsayıları için 0,10 ve altındaki değerler küçük etkiyi, 0,30 ve üstündeki değerler orta düzeydeki etkiyi, 0,50 ve üzerindeki değerler ise büyük etkiyi göstermektedir (Kline,1998).

Tablo 5. Dördüncü Sınıflara İlişkin Tanımlanan Modeldeki Yol Katsayıları ve Etki Büyüklükleri

\begin{tabular}{lcc}
\hline Yapısal İlişkiler & $\begin{array}{c}\text { Standarlaştırılmış } \\
\text { Yol Katsayısı (t-değeri) }\end{array}$ & Etki Büyüklüğü \\
\hline Matematiği Sevme $\rightarrow$ Matematik Başarısı & $0,20\left(7,14^{*}\right)$ & Küçük Etki \\
Matematiğe Olan İlgi $\rightarrow$ Matematik Başarısı & $0,09\left(2,87^{*}\right)$ & Küçük Etki \\
Matematiğe İlişkin Özgüven $\rightarrow$ Matematik Başarısı & $-0,58\left(-21,14^{*}\right)$ & Büyük Etki \\
Ev Ortamı $\rightarrow$ Matematik Başarısı & $-0,33\left(-14,28^{*}\right)$ & Orta Etki \\
Okul Ortamı $\rightarrow$ Matematik Başarısı & $-0,07\left(-2,89^{*}\right)$ & Küçük Etki \\
\hline
\end{tabular}

Not: ${ }^{*}$ işareti ,05 seviyesinde manidar bir etkiyi göstermektedir.

Tablo 5'ten elde edilen bilgilere göre, dördüncü sınıflara ilişkin yapısal eşitlik modelinde matematiği sevme ile matematik başarısı arasında $(\beta=0,20, \mathrm{p}<, 05)$ doğrudan pozitif yönlü anlamlı bir ilişki bulunmuştur. Ayrıca matematiği sevme değişkeninin matematik başarısı üzerindeki etki büyüklüğü küçük etki düzeyindedir. Matematiğe olan ilgi ile matematik başarısı arasındaki ilişki ise pozitif yönlü ve zayıftır $(\beta=0,09, \mathrm{p}<, 05)$. Matematiğe ilişkin özgüven ile matematik başarısı arasında $(\beta=-0,58, \mathrm{p}<, 05)$ negatif yönlü bir ilişki bulunmaktadır. Matematiğe ilişkin özgüven değişkeninin matematik başarısı üzerindeki etki düzeyi ise büyüktür. Ev ortamı değişkeni ile matematik başarısı arasında $(\beta=-0,33, \mathrm{p}<, 05)$ negatif yönlü bir ilişki bulunmuştur. Ev ortamı değişkeni matematik başarısını orta düzeyde etkilemektedir. Okul ortamı değişkeni ile matematik başarısı arasında ise $(\beta=-0,07, \mathrm{p}<, 05)$ negatif yönlü küçük bir ilişki bulunmaktadır. Dördüncü sınıflar için kurulan yapısal eşitlik modeline ilişkin regresyon denklemi aşağıdaki gibidir:

Matematik Başarısı $=(0,20 \mathrm{x}$ Matematiği Sevme $)+(0,09 \times$ Matematiğe Olan İlgi $)-(0,58 \mathrm{x}$ Matematiğe İlişkin Özgüven $)$ - (0,33 x Ev Ortamı) - (0,07 x Okul Ortamı)

Hata varyans $1=0,53 ; \mathrm{R}^{2}=0,47$.

Elde edilen bu regresyon denklemine göre, dördüncü sınıf öğrencilerinin matematik başarısının \%47'sini öğrencilere ilişkin matematiği sevme, matematiğe olan ilgi, matematiğe ilişkin özgüven değişkenleri ile birlikte ev ortamı ve okul ortamı değişkenleri açıklamaktadır. Bu değişkenlerden matematik başarısını en çok negatif yönde matematiğe ilişkin özgüven değişkeni açıklarken, onu yine negatif yönde ev ortamı değişkeni takip etmektedir.

Kurulan yapısal eşitlik modelinin sekizinci sınıf verisine uygulanmasından elde edilen sonuçlar aşağıda tablolar halinde gösterilmiştir. İlk olarak yapısal eşitlik modelinin, model veri uyumuna ilişkin elde edilen uyum indeks değerleri Tablo 6'da gösterilmiştir.

Tablo 6. Sekizinci Sınıflar için Kurulan Yapısal Eşitlik Modelinin Uyum İndeksleri

\begin{tabular}{|c|c|c|c|c|c|c|}
\hline & $\chi^{2}(s d)$ & RMSEA & SRMR & CFI & NNFI & GFI \\
\hline Yapısal Model & $2366,22(359)$ & 0,03 & 0,03 & 0,99 & 0,99 & 0,97 \\
\hline
\end{tabular}

Tablo 6 incelendiğinde sekizinci sınıflar için kurulan yapısal modelin uyum indeks değerlerinin ( $\chi^{2}(\mathrm{sd})$, RMSEA, SRMR, CFI, NNFI, GFI) kritik değerleri karşıladıkları görülmektedir. Bu sonuçlara göre yapısal eşitlik modelinin veriye uyum sağladığı görülmüştür. Model veri uyumu sağlandıktan sonra, kurulan yapısal eşitlik modeline ilişkin yol diyagramı Şekil 2'de gösterilmektedir. 


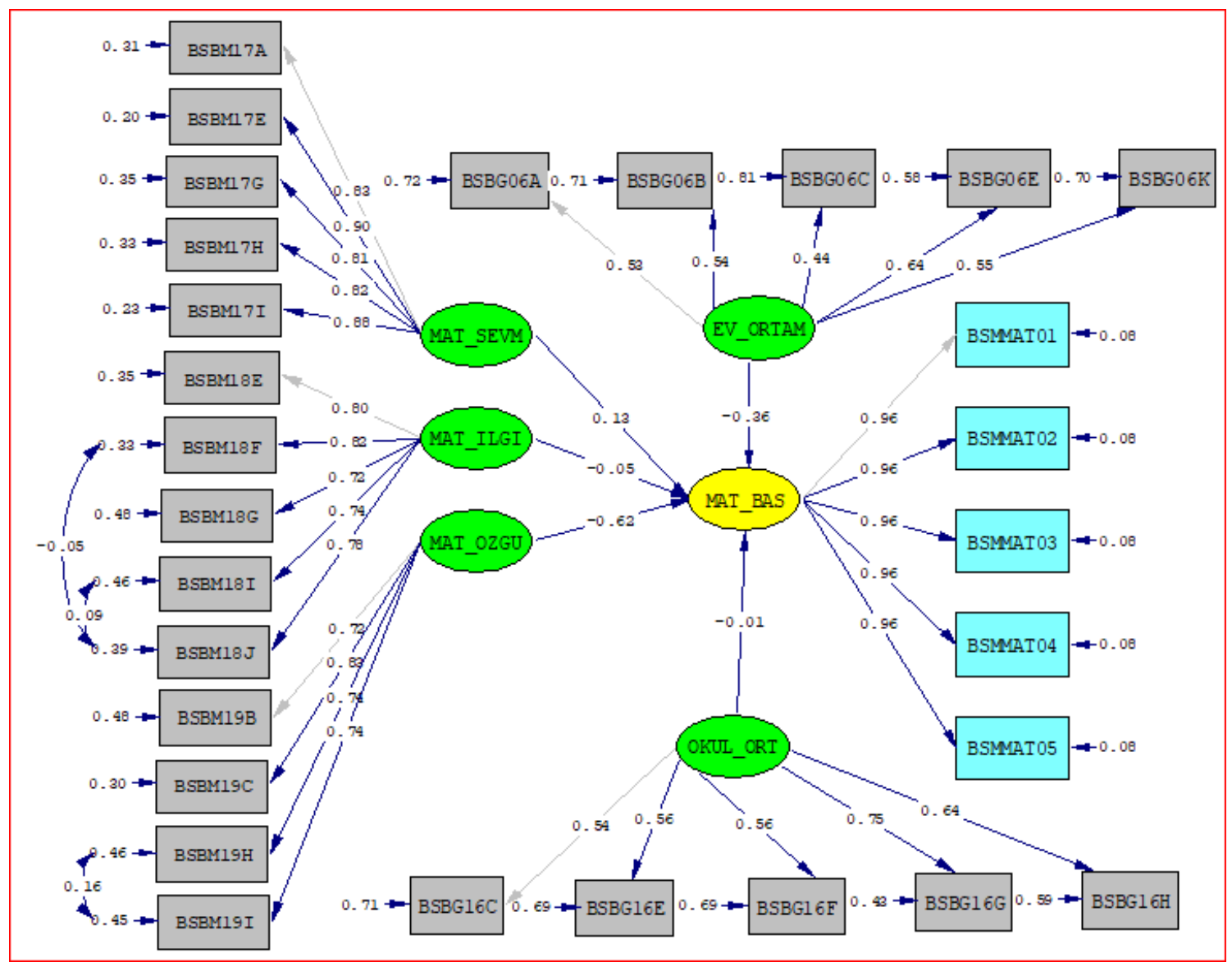

Şekil 2. Sekizinci Sınıflar İçin Kurulan Yapısal Eşitlik Modeline İlişkin Yol Diyagramı

Şekil 2'deki yol diyagramında standartlaştırılmış yol katsayıları, faktör yük değerleri ve hata değerleri gösterilmiştir. Standartlaştırılmış faktör yük değerlerinin hepsinin 0,30'dan büyük, standartlaştırılmış hata değerlerinin ise 0,90'dan küçük olması modelde yer alan maddelerin ilgili yapının çok iyi göstergesi olduğunu göstermektedir. Modelde gizil değişkenler arasındaki yol katsayıları (standartlaştırılmış katsayılar) ve etki büyüklüklerine ilişkin elde edilen değerler Tablo 7'de gösterilmiştir.

\section{Tablo 7. Sekizinci Sınıflara İlişkin Tanımlanan Modeldeki Yol Katsayıları ve Etki Büyüklükleri}

\begin{tabular}{ccc}
\hline Yapısal İlişkiler & $\begin{array}{c}\text { Standarlaştırılmış } \\
\text { Yol Katsayısı (t-değeri) }\end{array}$ & Etki Büyüklüğü \\
\hline Matematiği Sevme $\rightarrow$ Matematik Başarısı & $0,13\left(5,98^{*}\right)$ & Küçük Etki \\
M atematiğe Olan İlgi $\rightarrow$ Matematik Başarısı & $-0 ., 05\left(-2,97^{*}\right)$ & Küçük Etki \\
Matematiğe İlişsin Özgüven $\rightarrow$ Matematik Başarısı & $-0,62\left(-28,05^{*}\right)$ & Büyük Etki \\
Ev Ortamı $\rightarrow$ Matematik Başarısı & $-0,36\left(-20,42^{*}\right)$ & Orta Etki \\
Okul Ortamı $\rightarrow$ Matematik Başarısı & $-0,01(-0,73)$ & Küçük Etki \\
\hline
\end{tabular}

Not: * işareti ,05 seviyesinde manidar bir etkiyi göstermektedir.

Kurulan yapısal eşitlik modelinin sekizinci sınıflar düzeyindeki yol katsayıları incelendiğinde, matematiği sevme ile matematik başarısı arasında $(\beta=0,13, \mathrm{p}<, 05)$ doğrudan pozitif yönlü anlamlı bir ilişki vardır fakat bu ilişki küçük etki düzeyindedir. Matematiğe olan ilgi ile matematik başarısı arasındaki ilişki ise negatif yönlü ve zayıftır $(\beta=-0,05, \mathrm{p}<, 05)$. 
Matematiğe ilişkin özgüven ile matematik başarısı arasında $(\beta=-0,62, \mathrm{p}<, 05)$ negatif yönlü bir ilişki bulunmaktadır. Matematiğe ilişkin özgüven değişkeninin matematik başarısı üzerindeki etki düzeyi ise büyüktür. Ev ortamı değişkeni ile matematik başarısı arasında $(\beta=-0,36, p<, 05)$ negatif yönlü orta düzeyde bir ilişki bulunmaktadır. Okul ortamı değişkeni ile matematik başarısı arasında ise $(\beta=-0,01, \mathrm{p}>, 05)$ negatif yönlü ve anlamlı olmayan bir ilişki bulunmaktadır. Elde edilen bu sonuçlara göre, sekizinci sınıflar için elde edilen regresyon denklemi aşağıdaki gibidir:

Matematik Başarısı $=(0,13 \times$ Matematiği Sevme $)-(0,05 \times$ Matematiğe Olan İlgi $)-(0,62 \times$ Matematiğe İlişkin Özgüven $)$ - (0,36 x Ev Ortamı) - (0,01 x Okul Ortamı)

Hata varyans $1=0,51 ; \mathrm{R}^{2}=0,49$.

Regresyon denklemine göre, TIMSS 2015'e katılan sekizinci sınıf öğrencilerinin matematik başarısının \% 49'unu matematiği sevme, matematiğe olan ilgi, matematiğe ilişkin özgüven değişkenleri ile birlikte ev ortamı ve okul ortamı değişkenleri açıklamaktadır. Dördüncü sınıflarda da olduğu gibi sekizinci sınıflarda da matematik başarısını en çok matematiğe ilişkin özgüven değişkeni açıklamaktadır. Yine benzer şekilde matematik başarısını ikinci sırada negatif yönlü olarak ev ortamı değişkeni açıklamaktadır. Matematik başarısını yordayan değişkenlerin belirlenmesi için kurulan yapısal eşitlik modelinin dördüncü ve sekizinci sınıflarda test edilmesinden elde edilen sonuçların benzerlik gösterdiği görülmüştür.

\section{Sonuç, Tartışma ve Öneriler}

$\mathrm{Bu}$ araştırmada, TIMSS 2015 matematik testini alan dördüncü ve sekizinci sınıf öğrencilerinin matematik başarıları ile matematiği sevme, matematiğe olan ilgi, matematiğe ilişkin özgüven, ev ortamı ve okul ortamı değişkenleri arasındaki ilişki yapısal eşitlik modeli ile incelenmiştir. Bu amaç doğrultusunda hem yol modeli hem de ölçme modelini içeren hibrit model kurulmuştur. Analiz sonuçlarına göre hem dördüncü sınıf hem de sekizinci sınıf öğrencilerinin matematik başarısını en fazla açıklayan değişkenin, matematiğe ilişkin özgüven olduğu gözlenmiştir, ancak bu değişken matematik başarısını negatif yönde yordamaktadır. Bu değişken her iki sınıf düzeyinde de büyük etkiye sahiptir. Alan yazın incelendiği zaman bu sonucu destekleyen çalışmalar (Stankov ve Lee, 2014; Çavdar, 2015; Ölçülüoğlu, 2015) olduğu gibi matematiğe ilişkin özgüvenin öğrenci başarısını pozitif yönde etkilediği çalışmalar da mevcuttur (Pajares ve Kranzler, 1995; Doğan ve Barış, 2010; Koğar, 2012; Jiang, Song, Lee ve Bong, 2014; Yurt ve Sünbül; 2014; Şahin ve Yıldırım, 2016; Sarı vd., 2017). Bu durumun olası nedenlerinden biri olarak Stankov ve Lee (2014)'te belirtildiği üzere özgüven ya da öz yeterlik kavramının kültürler arasında farklı anlamlar ifade etmesi gösterilebilir. Kurulan yapısal modelde yer alan tüm değişkenler, öğrencilerin matematik başarısının dördüncü sınıf düzeyinde \% 47'sini açıklarken, sekizinci sınıf düzeyinde \% 49'unu açıklamaktadır.

Araştırma sonuçlarına göre dördüncü sınıf düzeyinde kurulan modelde öğrenci başarısını matematiğe ilişkin özgüven, ev ortamı ve okul ortamı değişkenleri negatif yönde yordarken, matematiği sevme ve matematiğe olan ilgi değişkenleri ise pozitif yönde yordamaktadır. Çavdar (2015), TIMSS 2011 Türkiye verileri üzerinden yaptığı çalışmasında da matematiğe ilişkin öz güven değişkeni matematik başarısını negatif yönde etkilemekteydi. Ayrıca, yine Aydın (2015) TIMSS 2011 sekizinci sınıf verilerini kullanarak yaptı̆̆ı çalışmada diğer değişkenler sabit tutulduğunda öğrencilerin matematik dersine ilişkin özgüven değişkenin, matematik başarıları ile yüksek düzeyde $(\gamma=-21.40)$ manidar bir ilişkiye sahip olduğu görülmüştür. Matematiğe ilişkin öz güven değişkeninden sonra dördüncü sınıflarda matematik başarısını en fazla yordayan ikinci değişkenin ev ortamı değişkeni olduğu görülmektedir ve bu değişken orta düzeyde bir etkiye sahiptir. 
Ev ortamı değişkenini oluşturan maddeler öğrencilerin evde bilgisayara, internete sahip olma gibi maddeleri içermekteydi. Öğrencilerin başarılarını etkileyen değişkenlerden biri olan evdeki kitap sayısının bir çok araştırmada başarıyı olumlu yönde etkilemesi göz önüne alındığında bu araştırmada analize dahil edilmemesi, çalışmanın sınırlılığı olarak kabul edilmektedir. Ev ortamı değişkenin matematik başarısını negatif yönde etkilemesine paralel olarak, Oral ve McGivney (2013) TIMSS 2011 verileri üzerinden yaptıkları çalışmalarında evde hergün bilgisayar kullanan öğrencilerden ziyade, haftada bir ya da iki defa bilgisayar kullanan öğrencilerin daha başarılı olduğu sonucu bulunmuştur. Okul ortamı değişkeni de öğrencilerin matematik başarılarında negatif ama küçük bir etkiye sahiptir. Okul ortamı değişkenini oluşturan maddelerin zorbalığa uğrama ile ilgili olduğu göz önüne alınırsa bu sonuç literatürle paralellik göstermektedir. Çünkü okul ortamı değişkenine ilişkin puanın yüksek olması zorbalığa uğrama düzeylerinin arttığı göstermekteydi. Fakat yapılan araştırmalarda okullarda zorbalığa maruz kalmayan öğrencilerin matematik başarıları daha yüksek bulunmuştur (Akyüz, 2014; Buluç, 2014; Ponzo, 2013; Sarı vd., Yavuz vd., 2017). Bu çalışmalardan elde edilen bulgular, çalışmada elde edilen olumsuz okul ortamı sonuçlarını desteklemektedir. Bu bulgulara göre zorbalığa sıklıkla uğrayan öğrencilerin akademik performansları düşmekte ve okullarına karşı olumsuz düşüncelere sahip olmaktadırlar (Strøm, Thoresen, Wentzel-Larsen ve Dyb, 2013). Türkiye' deki öğrencilerin zorbalığa maruz kalma sıklıklarının diğer ülkelerle karşılaştırıldığında fazla olduğu (Buluç, 2014) göz önüne alınarak okul ortamında yaşanan zorbalık olaylarının göz ardı edilmemesi gerekmektedir. Öğretmenler ve yöneticilerin bu olayları yakından takip edip, öğrencilerin kendilerini daha güvende hissettikleri bir okul ortamı oluşturulmalıdır.

Araştırmadan elde edilen sonuçlar sekizinci sınıf düzeyinde ele alındığ zaman, modele dahil edilen değişkenlerin öğrencilerin matematik başarılarını yordamadaki sıralamalarının ve etki büyüklüklerinin dördüncü sınıflardaki gibi olduğu görülmektedir. Ancak matematiğe olan ilgi dördüncü sınıf düzeyinde pozitif bir yordayıcı iken sekizinci sınıf düzeyinde negatif bir yordayıcı olmuştur. Çavdar (2015) yaptığı çalışmasında da sekizinci sınıf düzeyinde matematiğe olan ilgi değişkeni öğrencilerin başarılarını negatif yönde yordamaktaydı. TIMSS verisi üzerinden yapılan çalışmalar, ev ortamı değişkeninin öğrencilerin başarısını etkileyen önemli değişkenler arasında yer aldığını göstermektedir (Akyüz, 2006; Ersoy, 2007; Akyüz, 2014; Sarı vd., 2017). Ölçülüoğlu (2015), öğrencilerin TIMSS 2011 matematik başarısı üzerinde ev kaynaklarının etkisini incelediği çalışmasında; ev kaynaklarını bölgelere göre karşılaştırmış ve ev kaynağı ortalamasının yüksek olduğu bölgelerdeki öğrencilerin matematik başarısının daha yüksek olduğunu gözlemlemiştir. Yapılan bu çalışmada ise ev ortamı değişkeni, öğrencilerin matematik başarısını negatif yönde yordamaktadır.

Araştırma sonuçlarına göre hem dördüncü hem de sekizinci sınıf düzeyinde öğrencilerin matematik başrılarını açıklamada en önemli değişkenlerin sırasıyla mateamtiğe ilişkin özgüven ve ev ortamı değişkenleri olduğu görülmüştür. Çavdar (2015) yaptığı çalışmada TIMSS 2011 dördüncü sınıf düzeyinde matematik başarısını açıklayan en önemli değişkenin matematiğe ilişkin özgüven olduğu görülmüştür. Aşkın ve Gözkalp (2013) lojistik regresyon ve yapay sinir ağlarının yordama ve sınıflama güçlerini karşılaştırdığı çalışmalarında matematik başarılarında etkili faktörün öğrencinin özgüveni olduğu bulunmuştur. Büyüköztürk vd. (2014) yaptıkları TIMSS 2011 raporunda da hem Türkiye hem de TIMSS genelinde evdeki eğitsel kaynakaların matematik başarısı ile yüksek düzeyde ilişkisi bulunmuştur. Akyüz (2014) Türkiye, Singapur, ABD ve Finlandiya sekizinci sınıf öğrencilerinin öğrenci ve okul düzeylerindeki değişkenlerinin matematik başarıları ile ilişkisini incelediği çalışmasında tüm ülkelerde öğrenci düzeyinde özgüven ve evdeki eğitsel kaynakların matematik başarısını en fazla yordayan değişkenler olarak bulunmuştur. Bayar 
ve Bayar (2013), akademik başarı ile destekleyici ev ortamı arasında güçlü ve pozitif bir ilişkinin olduğunu belirtmektedir. Sarı vd. (2017) TIMSS 2015 sekizinci sınıf Türkiye verilerini kullanarak yaptıkları çalışmalarında öğrencilerin matematik başarılarını açıklayan en önemli değişkenlerden birinin evdeki eğitsel kaynaklar olduğu sonucuna ulaşılmıştır. Kupari ve Nissinen'de (2013) ev ortamının öğrencilerin başarıları ile yüksek düzeyde ilişkili olduğunu vurgulamışlardır. Arikan, Fons, Vijver ve Yağmur (2016) TIMSS 2007 ve TIMSS 2011 Türkiye ve Avusturya öğrencilerinin matematik başarılarını karşılaştırdıkları çalışmalarında bireysel farklılıkları açıklamada etkili olan en önemli değişkenlerin matematiğe ilişkin özgüven ve evdeki eğitsel kaynaklar olduğu sonucuna ulaşmışlardır.

Matematiği sevme ve matematiğe olan ilgi değişkenlerinin öğrenci başarısı üzerinde küçük etkiye sahip olduğu gözlenmiştir. Ancak bu değişkenler sekizinci sınıf düzeyinde matematiğe olan ilgi değişkeni hariç öğrenci başarısını pozitif yönde yordamaktadır. Öğrencilerin matematiğe karşı olumlu tutuma sahip olmalarının matematik başarısını arttırması beklenen bir durumdur. Sekizinci sınıf düzeyinde matematiğe olan ilgi değişkeninin öğrenci başarısını negatif yönde yordaması ise öğrenciler üzerindeki sınav kaygısının bir sonucu olarak düşünülebilir (Sarı vd., 2017).

Son olarak, modelde yer alan okul ortamı değişkeni de öğrencilerin matematik başarısı üzerinde küçük etkiye sahiptir ve başarıyı negatif yönde etkilemektedir. Bu durum araştırmanın diğer sonuçlarından biridir. Okul ortamı değişkeni olarak sadece dört maddenin olması ve bu maddelerinde okul ortamındaki zorbalık düzeylerini ölçmesi araştırmanın bir sınırlılığıdır. Ancak, Bayar ve Bayar (2013) okullardaki eğitim kalitesi için dört temel unsur olarak öğretmen, öğrenci, veli ve yöneticiler belirtir. Bu bağlamda, öğrenci görüşlerinin alındığı anketlerin yanında öğretmen ve yönetici görüşleri de alındığında, mateamatik başarısı üzerinde küçük etkiye sahip olan okul ortamı değişkenin etkisinin farklılaşabileceği düşünülebilir. Nitekim öğrencilerin daha iyi bir okul ortamına sahip olduğu zaman başarılarının arttığını ortaya koyan çalışmalar mevcuttur (Akyüz, 2006; Abazaoğlu, Yatağan, Y1ldızhan, Arifoğlu ve Umurhan, 2015).

$\mathrm{Bu}$ araştırma kapsamına dahil edilen değişkenler, öğrenci başarısının önemli bir kısmını açıklamaktadır. Öğrencilerin matematik başarısını pozitif yönde artırması beklenen değişkenlerin bu çalışmanın bulgularına göre öğrenci başarısını negatif yönde yordaması, bu araştırmanın çarpıcı sonuçları arasındadır. Bu durum yapılacak başka çalışmalarla yeniden incelenmelidir. Özellikle kültürler arası farklılıkların sonuçlar üzerinde önemli bir etkiye sahip olduğu göz önünde bulundurulursa, TIMSS 2015 çalışmasına katılan farklı ülkelerin dahil edildiği karşılaştırmalı araştırmaların yapılması önerilmektedir.

Son yıllarda medyanın dikkatleri çekmesi ile birlikte uluslararası sınavlar toplum tarafindan daha fazla ilgi görmektedir. Bunun karşılığı olarak, politika yapıcılar, bu sınavlardan elde edilen sonuçların nedenleri üzerine daha büyük bir önemle eğilmeli, ülkelerin eğitim sistemlerinin karşılaştırılmasına önemli düzeyde imkan sağlayan ikincil araştırma sonuçlarına da gereken önem gösterilmelidir.

\section{Referanslar}


TIMSS 2015 matematik başarısını etkileyen değişkenlerin yapısal eşitlik modeli ile incelenmesi

Abalı-Öztürk, Y. \& Şahin, Ç. (2015). Matematiğe ilişkin akademik başarı-özyeterlilik ve tutum arasındaki ilişkilerin belirlenmesi. The Journal of Academic Social Science Studies, 31, 343-366.

Abazaoğlu, İ., Yatağan, M., Yıldızhan, Y., Arifoğlu, A. \& Umurhan, Y. (2015). Öğrencilerin matematik başarısının uluslararası fen ve matematik eğilimleri araştırması sonuçlarına göre değerlendirilmesi. Turkish Studies-International Periodical for the Languages, Literature and History of Turkish or Turkic Volume, 10(7), 33-50.

Akyüz, G. (2006). Investigation of the effect of teacher and class characteristics on mathematics achievement in turkey and european union countries. Illkögretim Online, 5(2), 61-74.

Akyüz, G. (2014). The effects of student and school factors on mathematics achievement in TIMSS 2011. Eğitim ve Bilim, 39(172), 150-162.

Akyüz, G. \& Berberoglu, G. (2010). Teacher and classroom characteristics and their relations to mathematics achievement of the students in the TIMSS. New Horizons in Education, 58(1), 77-95.

Arikan, S., Fons, J.R., Vijver, V. \& Yağmur, K. (2016). Factors contributing to mathematics achievement differences of Turkish and Australian students in TIMSS 2007 and 2011. Eurasia Journal of Mathematics Sicence \& Technology Education, 12(8), 2039-2059.

Bandura, A. (1986). Social foundations of thought and action: A social cognitive theory. Englewood Cliffs, NJ: Prentice Hall.

Bayar, V. \& Bayar, S. A. (2013). TIMSS 2011 matematik başarısı ulusal değerlendirme raporu. Türk Eğitim Sendikası TIMSS 2011 Matematik Başarısı Ulusal Değerlendirme Raporu, Ankara. https://www.turkegitimsen.org.tr/upload_doc/00_2012_y/00_yok/TIMSS.docx adresinden edinilmiştir.

Bayrakçı, M. (2007). Sosyal öğrenme kuramı ve eğitimde uygulanması. Sakarya Üniversitesi Ĕ̈itim Fakültesi Dergisi, 14, 198-210.

Bloom, B. S. (2012). Insan nitelikleri ve okulda öğrenme (Çev. D. A. Özçelik). Ankara: Pegem Akademi.

Buluç, B. (2014). TIMSS 2011 sonuçları çerçevesinde, okul iklimi değişkenine göre öğrencilerin matematik başarı puanlarının analizi. 2014 Gazi Üniversitesi Endüstriyel Sanatlar Eğitim Fakültesi Dergisi, 33, 105-121.

Büyüköztürk, Ş., Çakan, M., Tan, Ş. \& Atar, H. Y. (2014). TIMSS 2011 ulusal matematik ve fen raporu. 8. siniflar. Ankara MEB: YEGİTEK Yayınları.

Büyüköztürk, Ş., Çakmak, E. K., Akgün, Ö. E., Karadeniz, Ş. \& Demirel, F. (2014). Bilimsel araştırma yöntemleri (16. Bask1). Ankara: Pegem Akademi.

Choi, K., Choi, T. \& McAninch, M. (2012). A comparative investigation of the presence of psychological conditions in high achieving eighth graders from TIMSS 2007 mathematics. ZDM: International Reviews on Mathematical Education, 44(2), 189 - 199. https://doi.org/10.1007/s11858-012-0401-6.

Cole, D. A. (1987). Utility of confirmatory factor analysis in test validation research. Journal of Consulting and Clinical Psychology, 55(4), 1019-1031.

Çalışkan, M. (2014). Bir derse yönelik duyuşsal giriş özelliklerinin belirlenmesi: Bir ölçme modeli önerisi. Kastamonu Ĕgitim Dergisi, 22(1), 57-68.

Çavdar, D. (2015). TIMSS 2011 matematik başarısının öğrenci ve öğretmen özellikleri ile ilişkisi. Yüksek Lisans Tezi, Gazi Üniversitesi Eğitim Bilimleri Enstitüsü, Ankara. 
Çokluk, Ö., Şekercioğlu G. \& Büyüköztürk, Ş. (2012). Sosyal bilimler için çok değişkenli istatistik SPPS ve LISREL uygulamalart. Ankara: Pegem Akademi.

Doğan, N. \& Barış, F. (2010). Tutum, değer ve özyeterlik değişkenlerinin TIMSS-1999 ve TIMSS-2007 sınavlarında öğrencilerin matematik başarılarını yordama düzeyleri. Ĕ̆itimde ve Psikolojide Ölçme ve Değerlendirme Dergisi, 1(1), 44-50.

Ersoy, Y. (2007). TIMSS-2007: Uluslararası matematik ve fen araştırması-II: başarıyı etkileyen örtük değişkenler ve genel eğilimler. [Çevrim-içi: http://www.f2e2ogretmen.com/dagarcigimiz/f2e2-522.pdf], Erişim tarihi: 27 Nisan 2018.

Henderson, A. T. \& Mapp, K. L. (2012). A new wave of evidence: The impact of school, family, and community connections on student achievement. Austin, TX: Southwest Educational Development Laboratory.

Jan, A. \& Husain, S. (2015). Bullying in elementary schools: Its causes and effects on students. Journal of Education and Practice, 6(19), 43-56.

Jeynes, W. (2005). A meta-analysis: Parental involvement and secondary student educational outcomes. Evaluation Exchange of the Harvard Family Research Project, 10 (4), 6.

Jöreskog, K. G. \& Sörbom, D. (1993). LISREL 8: Structural equation modeling with the SIMPLIS command language. New Jersey: Lawrence Erlbaum.

Khine, M. S., Al-Mutawah, M. \& Afari, E. (2015). Determinants of affective factors in mathematics achievement: Structural equation modeling approach. Journal of Studies in Education, 5(2), 199-211.

Kupari, P. \& Nissinen, K. (2013). Background Factors Behind Mathematics Achievement in Finnish Education Context: Explanatory Models Based On TIMSS 1999 and TIMSS 2011 Data. Paper presented in the 5th IEA International Research Conference. 26-28 Haziran, Singapur.

[Çevrim-içi: http://www.iea.nl/fileadmin/user_upload/IRC/IRC_2013/Papers/IRC2013_Kupari_Niss inen.pdf] Erişim Tarihi: 4 Aralık 2018.

Leder, G. C. \& Forgasz, H. J. (2006). Affect and mathematics education: PME perspectives. In A. Gutiérrez, \& P. Boero (Eds.), Handbook of research on the psychology of mathematics education: Past, present and future (1st ed., 403-427). Rotterdam, The Netherlands: Sense Publishers.

Lee, J. (2009). Universals and specifics of math self-concept, math self-efficacy, and math anxiety across 41 pisa 2003 participating countries. Learning and Individual Differences, $19,355-365$.

Leung, F. K. (2002). Behind the high achievement of east asian students. Educational Research and Evaluation, 8(1), 87-108.

Liu, S. \& Meng, L. (2010). Re-examining factor structure of the attitudinal items from TIMSS 2003 in cross-cultural study of mathematics self-concept, Educational Psychology: An International Journal of Experimental Educational Psychology, 30, 699-712. doi:10.1080/01443410.2010.501102.

Markey, S. M. (2009). The relationship between visual-spatial reasoning ability and math and geometry problem-solving. (PhD thesis). Available from ProOuest Dissertations and Theses database. (UMI No. 3385692).

Marsh, H. W. \& Hocevar, D. (1988). A new more powerful approach to multitrait multi method analyses: Application of second-order confirmatory factor analysis. Journal of Applied Psychology, 73, 107-117. 25 Eylül 2017 tarihinde http://psycnet.apa.org/index.cfm?fa=buy.optionToBuy\&id=1989-07244-001.pdf adresinden erişilmiştir. 
TIMSS 2015 matematik başarısını etkileyen değişkenlerin yapısal eşitlik modeli ile incelenmesi

Marsh, H.W., Balla, J. R. \& McDonald, R. P. (1988). Goodness-of-fit indexes in confirmatory factor analysis: The effect of sample size. Psychological Bulletin, 103, 391-410.

Martin, M. O., Mullis, I. V., Gonzales, E. J. \& Chrostowski, S. J. (2004). TIMSS 2003 international science report: Findings from IEA's trends in international mathematics and science study at the fourth and eighth grades. TIMSS \& PIRLS International Study Center, Lynch School of Education, Boston College.

Mcmillian, J. H. (2015). Sınıf içi değerlendirme (Çev: Arı, A.). Konya: Eğitim.

Mohammadpour, E. (2012). Factors accounting for mathematics achievement of Singaporean eighth-graders. The Asia-Pacific Education Researcher, 21(3), 507-518.

Mullis, I. V. S., Martin, M.O., Foy, P., \& Arora, A. (2012). TIMSS 2011 international results in mathematics. Chestnut Hill, MA: TIMSS \& PIRLS International Study Center, Boston College.

Oral, I. \& McGivney, E. (2013). Türkiye'de matematik ve fen bilimleri alanlarında ögrenci performansı ve başarının belirleyicileri TIMSS 2011 analizi. İstanbul: Eğitim Reformu Girişimi Raporu.

Ölçüoğlu, R. (2015). TIMMS 2011 Türkiye sekizinci sınıf matematik başarısını etkileyen değişkenlerin bölgelere göre incelenmesi. Yayımlanmamış Yüksek Lisans Tezi. Hacettepe Üniversitesi, Eğitim Bilimleri Enstitüsü, Ankara.

Ölçüoğlu, R. \& Çetin, S. (2016). TIMSS 2011 sekizinci sınıf öğrencilerinin matematik başarısını etkileyen değişkenlerin bölgelere göre incelenmesi. Eğitimde ve Psikolojide Ölçme ve Değerlendirme Dergisi, 7(1), 202-220. doi: 10.21031/epod.34424.

Özer, Y. \& Anıl, D. (2011). Öğrencilerin fen ve matematik başarılarını etkileyen faktörlerin yapısal eşitlik modeli ile incelenmesi. Hacettepe Üniversitesi Eğitim Fakültesi Dergisi, 41(41), 313-324.

Pajares, F. \& Kranzler, J. (1995). Self-efficacy beliefs and general mental ability in mathematical problem-solving. Contemporary Educational Psychology, 20(4), 426-443.

Ponzo, M. (2013). Does bullying reduce educational achievement? An evaluation using matching estimators. Journal of Policy Modeling, 35(6), 1057-1078.

Preacher, K. J., Zyphur, M. J. \& Zhang, Z. (2010). A general multilevel sem framework for assessing multilevel mediation. Psychological Methods, 15(3), 209-233.

Robitaille, D. F. \& Robeck, E. D. (1996). The character and the context of TIMSS. In D.F. Robitaille and R.A. Garden (Eds.), Research questions and study design. TIMSS monograph N. 2. Vancouver, Canada: Pasific Educational Press.

Sarı, M. H., Arıkan, S. \& Yıldızlı, H. (2017). 8. sınıf matematik akademik başarısını yordayan faktörler-TIMSS 2015. Eğitimde ve Psikolojide Ölçme ve Değerlendirme Dergisi, 8(3), 246-265.

Skryabin, M., Zhang, J., Liu, L. \& Zhang, D. (2015). How the ICT development level and usage influence student achievement in reading, mathematics, and science. Computers \& Education, 85, 49-58.

Stankov, L., Morony, S. \& Lee, Y. P. (2014). Confidence: The best non-cognitive predictor of academic achievement? Educational Psychology, 34, 9-28. doi: 10.1080/01443410.2013.814194.

Strøm, I. F., Thoresen, S., Wentzel-Larsen, T. \& Dyb, G. (2013). Violence, bullying and academic achievement: A study of 15-year-old adolescents and their school environment. Child Abuse \& Neglect, 37(4), 243-251. 
Tabachnick, B. G. \& Fidell, L.S. (2013). Multivariate statistics. New Jersey: Pearson Education.

TIMSS Uluslararası Veri tabanı (2013). 10 Aralı 2018 tarihinde http://timssandpirls.bc.edu/timss2011/international-database.html sayfasindan erişilmiştir.

Wilson, K. \& Narayan, A. (2016). Relationships among individual task self-efficacy, selfregulated learning strategy use and academic performance in a computer-supported collaborative learning environment. Educational Psychology, 36(2), 236-253. doi: 10.1080/01443410.2014.926312.

Wood, R. \& Bandura, A. (1989). Social cognitive theory of organizational management. Academy of Management Review, 14(3), 361-384.

Yavuz, H., Demirtaşlı, R., Yalçın, S. \& İlgün Dibek, M. (2017). Türk öğrencilerin TIMSS 2007 ve 2011 matematik başarısında öğrenci ve öğretmen özelliklerinin etkileri. Ĕ̆itim ve Bilim, 42(189), 27-47. doi:10.15390/EB.2017.6885

Yayan, B. (2003). Üçüncü uluslararası matematik ve fen çalışmasl-tekrar (TIMSS-R) daki matematik başarısının kültürler arası karşılaştırması. (Yüksek lisans tezi). Orta Doğu Teknik Üniversitesi, Ankara.

Yıldırım, H. H., Yıldırım, S., Ceylan, E. \& Yetişir, M. İ. (2013). Türkiye Perspektifinden TIMSS 2011 Sonuçları. Türk Eğitim Derneği Tedmem Analiz Dizisi I: Ankara [Çevrim-içi: http://portal.ted.org.tr/genel/yayinlar/timmsarastirmaraporu.pdf]. Erişim Tarihi: 25 Temmuz 2017.

Yılmaz, H. R. \& Bindak, R. (2016). Ortaokul öğrencilerinde matematik başarısının matematik kaygısı, sınav kaygısı ve bazı demografik değișkenlerle ilişkisinin incelenmesi. Muğla Sitkı Koçman Üniversitesi Ĕ̈itim Fakültesi Dergisi, 3(2), 30-42.

Yurdugül, H. (2006). Paralel, eşdeğer ve konjenerik ölçmelerde güvenirlik katsayılarının karş1laştırılması. Ankara Üniversitesi Eğitim Bilimleri Fakültesi Dergisi, 39 (1), 15-37.

Yurt, E. \& Sünbül, A. M. (2014). Sekizinci sınıf öğrencilerinin matematik başarılarını açıklayan bir yapısal eşitlik modeli. Kuram ve Uygulamada Eğitim Bilimleri, 14(4), 1629-1653.

Yücel, C. \& Karadağ, E. (2016). TIMSS 2015 Türkiye: Patinajdaki eğitim. Eskişehir: Eskişehir Osmangazi Üniversitesi Eğitim Fakültesi. 25 Nisan 2018 tarihinde http://www.egitim.ogu.edu.tr/files/1Z5_TIMSS_2015.pdf adresinden erişilmiştir. 